\title{
Association between peripheral arterial disease and creactive protein in the japanese-brazilian population
}

\section{Avaliação da associação entre doença arterial obstrutiva periférica e níveis aumentados de proteína C-reativa em população nipo-brasileira}

\author{
Luciana Garofolo ${ }^{1 ;}$ Sandra Roberta G. Ferreira ${ }^{2}$; Fausto Miranda Júnior, TCBC-SP3
}

A B S T R A C T

\begin{abstract}
Objective: To evaluate the relationship between peripheral arterial disease and elevated levels of C-reactive protein in the Japanese-Brazilian population of high cardiovascular risk. Methods: We conducted a cross-sectional study derived from a population-based study on the prevalence of diabetes and associated diseases in the Japanese-Brazilian population. One thousand, three hundred and thirty individuals aged e" 30 underwent clinical and laboratory examination, including measurement of ultrasensitive C-reactive protein. The diagnosis of peripheral arterial disease was performed by calculating the ankle-brachial index. We considered with peripheral arterial disease patients who had ankle-brachial index $d^{\prime \prime} 0.9$. After applying the exclusion criteria, 1,038 subjects completed the study. Results: The mean age of the population was 56.8 years; $46 \%$ were male. The prevalence of peripheral arterial disease was $21 \%$, with no difference between genders. Data analysis showed no association between peripheral arterial disease and ultrasensitive C-reactive protein. Patients with ankle-brachial index $d$ " 0.70 showed higher values of ultrasensitive C-reactive protein and worse cardiometabolic profile. We found a positive independent association of peripheral arterial disease with hypertension and smoking. Conclusion: The association between low levels of ankle-brachial index and elevated levels of ultrasensitive C-reactive protein may suggest a relationship of gravity, aiding in the mapping of highrisk patients.
\end{abstract}

Key words: Peripheral arterial disease. C-reactive protein. Atherosclerosis. Homocysteine.

\section{INTRODUCTION}

$\mathrm{D}$ espite changes in lifestyle and the growing therapeutic arsenal, cardiovascular diseases remain the leading cause of morbidity and mortality, especially in emerging developed countries. Twenty-year data from the Ministry of Health on the Health System showed that cardiovascular diseases are the leading cause of death in Brazil for both genders. In 2006, they accounted for $29.4 \%$ of deaths in the country, while neoplasia caused $15.1 \%{ }^{1}$.

Cardiovascular diseases arise by large from the atherosclerotic process, so the study and understanding of new risk factors for atherosclerosis are needed to identify individuals at risk and also for the development of new therapeutic strategies. Peripheral arterial atherosclerotic disease is increasingly prevalent in modern society due in part to the increase in life expectancy, affecting 202 million people worldwide in 2010. During the last decade there was a $28.7 \%$ increase in the prevalence of the disease in countries of low and middle income per capita, and 13.1\% in high-income ones ${ }^{2}$.

The pathophysiology of atherosclerosis is complex and multifactorial. The initial change in this process is endothelial dysfunction resulting from various factors, such as hypertension, diabetes mellitus, hypercholesterolemia, and smoking. During all phases of the atherosclerotic process there is release of cytokines, among them interleukin-6 (IL6), which is primarily responsible for the hepatic stimulation for the release of $\mathrm{C}$-reactive protein (CRP), the main acute phase protein in the inflammation process 3,4 .

Thus, atherosclerosis is regarded as a dynamic and progressive disease, arising from the combination of endothelial dysfunction and inflammation. Endothelial dysfunction is characterized by decreased production of nitric oxide and increased expression of adhesion molecules. These molecules promote the internalization of monocytes, which transform into macrophages, releasing IL6, stimulating the release of $C R P$, which in turn promotes the reduction

1. Post-Graduation Program, Interdisciplinary Surgical Science, Unversidade Federal de São Paulo (UNIFESP), São Paulo, Brazil; 2. Faculdade de Saúde Pública, Universidade de São Paulo (USP), São Paulo, Brazil; 3. Department of Surgery, Universidade Federal de São Paulo (UNIFESP), São Paulo, Brazil. 
of nitric oxide, stimulates the release of IL- 6 and the expression of endothelial adhesion molecules, perpetuating the inflammatory response 3 . CRP is currently considered the main clinical marker of inflammation. Its involvement in the atherosclerotic process has been discussed for decades.

The relationship between CRP and cardiovascular disease has been investigated mainly in the coronary territory ${ }^{5,6}$. Observational studies have consistently shown that elevated CRP levels are associated with increased risk for coronary heart disease and its dosage aids in the prediction of disease ${ }^{5,6}$. However, these studies provide only limited and indirect information about the performance of the marker in predicting disease ${ }^{7}$.

Currently, there is great interest about the real role of CRP in atherosclerosis: a causal factor or just a mediator of disease? The association between CRP and peripheral arterial disease (PAD) has been studied, however so much less extensively than in the coronary field ${ }^{8}$.

Our group conducted a population-based study on the prevalence of diabetes mellitus and associated diseases in Japanese immigrants and their descendants in Brazil. Japanese populations of migrant origin have high rates of diabetes and other cardiovascular risk factors ${ }^{9}$. A high prevalence of chronic diseases suggests that exposure to a different lifestyle exacerbates a genetic tendency to accumulate fat, increasing cardiovascular risk. These are genetically homogeneous populations, with unfavorable cardiometabolic profile, which contributes to the study of PAD and other complications of atherosclerosis ${ }^{10,11}$. Therefore, this population represents an opportunity to investigate the relationship of PAD with new risk factors, such as CRP.

\section{METHODS}

The study was conducted in the JapaneseBrazilian population living in Bauru, São Paulo, Brazil. Male and female individuals, aged e" 30 years were invited to participate. Details on the recruitment and selection of the sample population were previously described by the authors ${ }^{10,11}$

The study was approved by the Ethics in Research Committee of the Federal University of São Paulo, under number 1544/10, and a free and informed consent was obtained from all participants. One thousand, three hundred and thirty participants were interviewed about clinical and nutritional status and scheduled for clinical and laboratory evaluation. Data on smoking and history of previous diseases were obtained. The clinical examination included anthropometric measures, blood pressure and ankle-brachial index (ABI). Blood sample was obtained after 12 hours of fasting for laboratory testing, including ultrasensitive Creactive protein (CRP). After applying the exclusion criteria (incomplete data, CRP > 10mg/L and ABI > 1.40), 1,038 subjects completed the study.
Factors of conventional and non-conventional risk: since the population is of Asian origin, we chose to use the values of Body mass index (BMI) recommended by the Japan Society for the Study of Obesity (JASO) ${ }^{12}$. Values of waist-hip ratio used were those recommended by the World Health Organization (WHO) ${ }^{13}$.

Hypertension was diagnosed in those who, during the data collection, mentioned they have the disease and were undergoing treatment, and in those who had, during the physical examination, pressure values higher than $140 \times 90 \mathrm{mmHg}^{14}$. For the diagnosis of dyslipidemia, we used the reference values recommended by the National Cholesterol Education Program (NCEP) ${ }^{15}$. We considered diabetic patients who reported and were receiving drug treatment for the disease, and those who were diagnosed during the study according to the criteria of the American Diabetes Association (ADA) ${ }^{16}$.

Concentrations of uric acid up to $6 \mathrm{mg} / \mathrm{dL}$ for women and up to $7 \mathrm{mg} / \mathrm{dL}$ for men were considered normal. The cutoff value for homocysteine was $15 \mathrm{mmol} / \mathrm{L}{ }^{17}$, while for $C R P$, the one corresponding to the population median value, which was $1.1 \mathrm{mg} / \mathrm{L}$. Individuals with values of CRP higher than $10 \mathrm{mg} / \mathrm{L}$ were excluded. Glucose and plasma lipoproteins were determined by enzymatic methods. Concentrations of CRP were determined by chemiluminescence.

The diagnosis of PAD was performed by using an $8 \mathrm{MHz}$ continuous wave doppler device (Imbracios $®$ ). The $A B I$ was calculated as the quotient of auscultated pressure in the arteries of the ankle by the highest pressure obtained in the brachial arteries. As recommended by the TASC II (Transatlantic Society Consensus) ${ }^{18}$, we considered abnormal a value d" 0.9 and $>1.40$. We also stratified $A B \mid$ into three categories: $d$ " 0.70 , from 0.71 to 0.90 and $>$ $0.90^{19}$.

For the descriptive analysis, we used percentages, mean and standard deviations of the subjects' variables grouped according to the presence of PAD or to the $A B I$ values ( $d$ " $0.70 ; 0.71$ to $0.90 ; e^{\prime \prime} 0.90$ ). We verified the existence of associations between variables through the use of chi-square and prevalence ratios (PR). For the comparison of variables mean values, according to the presence of PAD to the ABI values, we used the Student $t$ test or analysis of variance, respectively. We applied the model of Poisson regression with robust variance in obtaining the PR of PAD according to the CRP median. We adopted a similar procedure to obtain the values of odds ratios according to the $A B I$ values ( $d$ " 0.70; from 0.71 to 0.90 ; $\mathrm{e}^{\prime \prime}$ 0.90) and median CRP.

\section{RESULTS}

The mean age of the 1,038 Japanese-Brazilians evaluated was 56.8 years; $46 \%$ were male. The mean values of BMI, waist-hip ratio, blood pressure, fasting 
glucose, triglycerides, uric acid and homocysteine levels were significantly higher in men. Total cholesterol, LDLcholesterol, HDL-cholesterol and CRP were significantly higher in women.

Table 1 shows the prevalence of conventional risk factors, CRP and homocysteine, in the population studied. Especially among men, we observed a high frequency of smoking $(p<0.01)$. Arterial hypertension did not differ between genders. As for disorders of glucose tolerance, the prevalence of DM was significantly higher among men (38.7\% versus $31.7 \%, p=0.008)$, who also more often presented hypertriglyceridemia, low HDLcholesterol, hyperuricemia and hyperhomocysteinemia. Higher values of LDL-cholesterol and CRP were more frequent in women.

The prevalence of PAD was $21.1 \%(n=219)$, with no difference between genders (19.2\% vs. $22.7 \%$ ), and was higher in subjects aged e" 60 years with hypertension and hyperhomocysteinemia. CRP was not associated with PAD (Table 2). In the adjusted analysis, we found a correlation between PAD and hypertension and current smoking, and no relationship of PAD with CRP (Table 3). In ABI stratified analysis, we observed a relation between PAD and hypertension and current smoking, and no relationship of PAD with CRP (Table 4).

The analysis of the means, according to the stratification of the $A B I$, showed higher mean CRP in patients with $A B I d " 0.70$, but without statistical significance. Still, the mean age of participants with $A B I d " 0.70$ was higher than in other categories. The same occurred with the mean fasting and two-hour glucose, homocysteine, systolic blood pressure and number of cigarettes smoked per day (Table 5).

Furthermore, $70 \%$ of individuals with $A B I d^{\prime \prime} 0.70$ had diabetes mellitus and increased WHR values (Table 6).

\section{DISCUSSION}

We found a high prevalence of PAD $(21.1 \%)$ in this population of Japanese-Brazilians. Given that the population presented unfavorable cardiometabolic profile, this high prevalence was expected. Another study, analyzing patients at high cardiovascular risk, found high rates of $P A D 20$

The risk factors independently associated with PAD were smoking and hypertension in both genders. CRP was not independently associated with PAD. However, with the stratification of the $A B I$, we found higher values of this variable in those with $A B I d " 0.70$, but without statistical significance. Nonetheless, this subgroup of patients with $A B I d^{\prime \prime} 0.70$ was composed of only 20 individuals, which makes the statistical analysis difficult. Still, individuals with more advanced disease

Table 1 - Prevalence of the main cardiovascular risk factors in the Japanese-Brazilian population.

\begin{tabular}{|c|c|c|c|c|c|c|}
\hline \multirow[t]{3}{*}{ Variable } & & \multicolumn{2}{|c|}{ Gender } & \multirow{2}{*}{\multicolumn{2}{|c|}{ Total $(n=1038)$}} & \multirow[t]{3}{*}{$p$ value } \\
\hline & & \multirow{2}{*}{$\begin{array}{c}\text { Male } \\
(n=473) \\
\%\end{array}$} & \multirow{2}{*}{$\begin{array}{c}\text { Female } \\
(n=565) \\
\%\end{array}$} & & & \\
\hline & & & & $\mathrm{N}$ & $\%$ & \\
\hline Age & $>60$ years & 40.0 & 40.7 & 419 & 40.4 & 0.806 \\
\hline Smoking & No & 46.2 & 88.8 & 717 & 69.3 & $<0.001$ \\
\hline & Yes (past) & 19.3 & 6.9 & 130 & 12.6 & \\
\hline & Yes (current) & 34.5 & 4.3 & 187 & 18.1 & \\
\hline Abdominal obesity ${ }^{1}$ & & 25.7 & 72.9 & 532 & 51.4 & $<0.001$ \\
\hline Body mass index & $<23 \mathrm{~kg} / \mathrm{m} 2$ & 27.8 & 37.7 & 344 & 33.2 & 0.001 \\
\hline & 23.0 a $24.9 \mathrm{~kg} / \mathrm{m} 2$ & 22.6 & 23.0 & 237 & 22.9 & \\
\hline & $>25 \mathrm{~kg} / \mathrm{m} 2$ & 49.6 & 39.3 & 456 & 43.9 & \\
\hline Arterial hypertension & & 47.2 & 43.9 & 471 & 45.4 & 0.295 \\
\hline Glucose tolerance & Normal & 3.4 & 7.5 & 58 & 5.6 & 0.008 \\
\hline & GJA & 35.9 & 36.7 & 377 & 36.4 & \\
\hline & TGD & 22.0 & 24.1 & 240 & 23.1 & \\
\hline & DM & 38.7 & 31.7 & 362 & 34.9 & \\
\hline Hypercholesterolemia & & 60.0 & 64.1 & 646 & 62.2 & 0.182 \\
\hline Low HDL & & 16.5 & 9.0 & 129 & 12.4 & $<0.001$ \\
\hline Increased LDL & & 43.1 & 52.7 & 502 & 48.4 & 0.002 \\
\hline Hypertriglyceridemia & & 72.3 & 58.2 & 671 & 64.6 & $<0.001$ \\
\hline CRP & $1.1-9.9$ & 46.7 & 54.5 & 529 & 51.0 & 0.012 \\
\hline Homocysteine & $>15$ mg/dL & 22.7 & 7.8 & 119 & 14.5 & $<0.001$ \\
\hline High uric acid & & 54.3 & 75.4 & 683 & 65.7 & $<0.001$ \\
\hline
\end{tabular}

${ }^{1}$ WHR waist-hip ratio 
Table 2 - Number, percentage and prevalence ratios (PR) with respective 95\% confidence intervals (95\% CI) for JapaneseBrazilians according to the presence of PAD and demographic, anthropometric, clinical and biochemical variables.

\begin{tabular}{|c|c|c|c|c|c|c|c|}
\hline \multirow[t]{2}{*}{ Variable } & & \multicolumn{3}{|c|}{ DAOP } & \multirow[t]{2}{*}{ Chi-square } & \multirow[t]{2}{*}{ PR } & \multirow[t]{2}{*}{$95 \% \mathrm{Ci}$} \\
\hline & & $\begin{array}{c}\text { Yes } \\
(n=219) \\
\%\end{array}$ & $\begin{array}{c}\text { No } \\
(n=819) \\
\%\end{array}$ & $\begin{array}{c}\text { Total } \\
(\mathrm{n}=1038) \\
\mathrm{N}\end{array}$ & & & \\
\hline \multirow[t]{2}{*}{ Gender } & Female & 22.7 & 77.3 & 565 & 1.80 & 1 & \\
\hline & Male & 19.2 & 80.8 & 473 & & 0.85 & $0.67-1.08$ \\
\hline Age & $>60$ years & 26.0 & 74.0 & 419 & & 1.46 & $1.16-1.85$ \\
\hline \multirow[t]{2}{*}{ Smoking } & Past & 20.3 & 79.7 & 187 & 0.39 & 0.97 & $0.71-1.33$ \\
\hline & Current & 23.1 & 76.9 & 130 & & 1.10 & $0.78-1.56$ \\
\hline Abdominal obesity (WHR) 1 & & 22.0 & 78.0 & 532 & 0.57 & 1.10 & $0.86-1.39$ \\
\hline \multirow[t]{3}{*}{ Body mass index } & $<23 \mathrm{~kg} / \mathrm{m}^{2}$ & 22.1 & 77.9 & 344 & 3.10 & 1 & \\
\hline & 23.0 a $24.9 \mathrm{~kg} / \mathrm{m}^{2}$ & & 24.1 & 75.9 & 237 & 1.09 & $0.81-1.47$ \\
\hline & $>25 \mathrm{~kg} / \mathrm{m}^{2}$ & 18.6 & 81.4 & 456 & & 0.84 & $0.64-1.11$ \\
\hline Hypertension & & 25.1 & 74.9 & 471 & 8.1 & 1.41 & $1.11-1.78$ \\
\hline \multirow[t]{4}{*}{ Glucose tolerance } & Normal & 13.8 & 86.2 & 58 & 4.40 & 1 & \\
\hline & GJA & 19.4 & 80.6 & 377 & & 1.40 & $0.71-2.76$ \\
\hline & TGD & 24.6 & 75.4 & 240 & & 1.78 & $0.90-3.52$ \\
\hline & DM & 21.8 & 78.1 & 362 & & 1.58 & $0.81-3.10$ \\
\hline Hypercholesterolemia & & 21.4 & 78.6 & 646 & 0.07 & 1.03 & $0.81-1.32$ \\
\hline Low HDL & & 22.5 & 77.5 & 129 & 0.17 & 1.08 & $0.72-1.52$ \\
\hline High LDL & & 21.3 & 78.7 & 502 & 0.03 & 1.02 & $0.81-1.29$ \\
\hline Hypertriglyceridemia & & 21.3 & 78.7 & 671 & 0.05 & 1.03 & $0.80-1.32$ \\
\hline CRP & $1.1-9.9$ & 22.5 & 77.5 & 529 & 1.26 & 1.15 & $0.90-1.45$ \\
\hline Homocysteine & $>15 \mathrm{mg} / \mathrm{dL}$ & 29.4 & 70.6 & 119 & 5.36 & 1.47 & $1.07-2.02$ \\
\hline
\end{tabular}

${ }^{1}$ WHR waist-hip ratio.

Table 3 - Values of prevalence ratios (PR) with their respective 95\% confidence intervals (95\% CI) for Japanese-Brazilians according to the presence of PAD and other variables (final and initial model).

\begin{tabular}{|c|c|c|c|c|c|}
\hline \multirow[t]{2}{*}{ Variable } & & \multicolumn{2}{|c|}{ Initial model } & \multicolumn{2}{|r|}{ Final model } \\
\hline & & PR & $95 \% \mathrm{Ci}$ & PR & $95 \% \mathrm{Ci}$ \\
\hline \multirow[t]{2}{*}{ CRP } & $<1.1$ & 1 & & 1 & \\
\hline & $1.1-9.9$ & 1.00 & $0.73-1.38$ & 1.03 & $0.76-1.39$ \\
\hline \multirow[t]{2}{*}{ Homocysteine } & $<15 \mathrm{mg} / \mathrm{dL}$ & 1 & & 1 & \\
\hline & $>15 \mathrm{mg} / \mathrm{dL}$ & 1.25 & $0.88-1.77$ & 1.26 & $0.89-1.78$ \\
\hline \multirow[t]{3}{*}{ Smoking } & No & 1 & & 1 & \\
\hline & Yes (past) & 1.45 & $0.91-2.31$ & 1.44 & $0.92-2.33$ \\
\hline & Yes (current) & 2.14 & $1.32-3.50$ & 2.16 & $1.34-3.48$ \\
\hline \multirow[t]{2}{*}{ Age } & ? 60 years & 1 & & 1 & \\
\hline & $>60$ years & 0.98 & $0.71-1.36$ & 0.94 & $0.69-1.23$ \\
\hline \multirow[t]{2}{*}{ Gender } & Female & 1 & & 1 & \\
\hline & Male & 0.66 & $0.42-1.02$ & 0.66 & $0.44-1.01$ \\
\hline \multirow[t]{2}{*}{ Arterial hypertension } & No & 1 & & 1 & \\
\hline & Yes & 1.61 & $1.12-2.31$ & 1.56 & $1.12-2.22$ \\
\hline \multirow[t]{4}{*}{ Glucose tolerance } & Normal & 1 & & & \\
\hline & GJA & 0.67 & $0.38-1.21$ & & \\
\hline & TGD & 0.76 & $0.42-1.38$ & & \\
\hline & DM & 0.66 & $0.37-1.17$ & & \\
\hline
\end{tabular}


Table 4 - Values of the odds ratios and their 95\% confidence intervals (95\% Cl) for Japanese-Brazilians according to the ankle-brachial index and other variables (final and initial model).

\begin{tabular}{|c|c|c|c|c|c|}
\hline \multirow[t]{2}{*}{ Variable } & & \multicolumn{2}{|c|}{ Initial model } & \multicolumn{2}{|r|}{ Final model } \\
\hline & & PR & $95 \% \mathrm{Ci}$ & $\mathrm{PR}$ & $95 \% \mathrm{Ci}$ \\
\hline \multirow[t]{2}{*}{ CRP } & $<1.1 \mathrm{mg} / \mathrm{L}$ & 1 & & 1 & \\
\hline & $1.1-9.9 \mathrm{mg} / \mathrm{L}$ & 0.97 & $0.55-1.72$ & 1.04 & $0.61-1.78$ \\
\hline \multirow[t]{2}{*}{ Homocysteine } & $<15 \mathrm{mg} / \mathrm{dL}$ & 1 & & 1 & \\
\hline & $>15 \mathrm{mg} / \mathrm{dL}$ & 1.51 & $0.73-3.15$ & 1.52 & $0.73-3.15$ \\
\hline \multirow[t]{3}{*}{ Smoking } & No & 1 & & 1 & \\
\hline & Yes (past) & 1.88 & $0.85-4.17$ & 1.89 & $0.86-4.18$ \\
\hline & Yes (current) & 4.45 & $1.62-12.24$ & 4.36 & $1.64-11.60$ \\
\hline \multirow[t]{2}{*}{ Age } & $<60$ years & 1 & & 1 & \\
\hline & $>60$ years & 0.96 & $0.55-1.66$ & 0.96 & $0.55-1.66$ \\
\hline \multirow[t]{2}{*}{ Gender } & Female & 1 & & 1 & \\
\hline & Male & 0.45 & $0.21-0.94$ & 0.50 & $0.25-0.99$ \\
\hline \multirow[t]{2}{*}{ Arterial hypertension } & No & 1 & & 1 & \\
\hline & Yes & 2.20 & $1.24-3.91$ & 2.25 & $1.28-3.95$ \\
\hline \multirow[t]{4}{*}{ Glucose tolerance } & Normal & 1 & & & \\
\hline & GJA & 0.57 & $0.16-2.09$ & & \\
\hline & $\mathrm{TGD}$ & 0.71 & $0.19-2.67$ & & \\
\hline & DM & 0.67 & $0.18-2.47$ & & \\
\hline
\end{tabular}

(ABI d" 0.70) were those with the worst cardiometabolic profile, which can also interfere with CRP levels, a phenomenon called reverse causality, ie, the atherosclerotic plaque being a focus of inflammation, observed changes in CRP values could reflect only the inflammatory activity in the plate caused by other risk factors ${ }^{21}$. Elevated CRP levels may be secondary to several factors, such as smoking, changes in the concentrations of total cholesterol, HDL-cholesterol, LDL-cholesterol, triglycerides and blood glucose, blood pressure and BMI in up to $78 \%$ of men and $67 \%$ of women ${ }^{22}$. CRP therefore participates in the atherosclerotic process; however, its real role is still debatable, ie, if it is only a mediator of disease severity or is causally associated with it.

Table 5 - Mean values and standard deviation (SD) of demographic, anthropometric, clinical and biochemical variables of Japanese-Brazilians according to the values of the ankle-brachial index.

\begin{tabular}{|c|c|c|c|c|c|c|c|c|}
\hline \multirow{3}{*}{$\begin{array}{l}\text { Variable } \\
\text { Age (years) }\end{array}$} & \multicolumn{7}{|c|}{ Ankle-brachial Index } & \multirow[t]{2}{*}{$\mathbf{P}$} \\
\hline & \multicolumn{2}{|c|}{$\begin{array}{c}<0,70 \\
\text { Mean (SD) }\end{array}$} & \multicolumn{2}{|c|}{$\begin{array}{c}0,71-0,90 \\
\text { Mean (SD) }\end{array}$} & \multicolumn{2}{|c|}{$\begin{array}{c}>0,90 \\
\text { Mean (SD) }\end{array}$} & \multirow{2}{*}{$\begin{array}{c}\begin{array}{c}\text { F-Statistic } \\
\text { (ANOVA) }\end{array} \\
10.14\end{array}$} & \\
\hline & 65.1 & $(12.7)$ & 59.3 & $(13.2)$ & 56.0 & $(12.3)$ & & $<0.001$ \\
\hline Number of cigarettes per day * & 22.5 & $(6.1)$ & 17.9 & $(6.7)$ & 17.3 & $(7.8)$ & 1.99 & 0.141 \\
\hline WHR & 0.91 & $(0.08)$ & 0.87 & $(0.07)$ & 0.88 & $(0.08)$ & 3.06 & 0.047 \\
\hline BMI $\left(\mathrm{kg} / \mathrm{m}^{2}\right)$ & 25.2 & $(4.8)$ & 24.4 & $(3.7)$ & 24.9 & $(3.8)$ & 1.34 & 0.263 \\
\hline $\mathrm{DBP}(\mathrm{mmHg})$ & 85.2 & $(11.7)$ & 79.7 & $(13.9)$ & 79.1 & $(13.2)$ & 2.09 & 0.125 \\
\hline $\mathrm{SBP}(\mathrm{mmHg})$ & 151.3 & $(23.0)$ & 137.6 & $(27.5)$ & 131.2 & $(23.4)$ & 9.86 & $<0.001$ \\
\hline Fasting blood glucose $(\mathrm{mg} / \mathrm{dl})$ * & 148.0 & $(49.1)$ & 120.5 & $(28.3)$ & 124.9 & $(35.2)$ & 6.56 & 0.002 \\
\hline Two-hour glucose $(\mathrm{mg} / \mathrm{dl})$ * & 239.2 & $(115.9)$ & 164.1 & $(70.4)$ & 162.2 & $(77.0)$ & 7.45 & 0.001 \\
\hline Total cholesterol (mg/dl) & 209.3 & $(31.2)$ & 214.3 & $(40.8)$ & 214.8 & $(43.1)$ & 0.17 & 0.840 \\
\hline $\mathrm{HDL}(\mathrm{mg} / \mathrm{dl})$ * & 49.5 & $(10.8)$ & 50.4 & $(10.2)$ & 51.4 & $(11.7)$ & 0.65 & 0.523 \\
\hline LDL cholesterol (mg/dl) & 126.1 & $(26.5)$ & 130.0 & $(38.8)$ & 130.6 & (38.1) & 0.15 & 0.864 \\
\hline Triglycerides $(\mathrm{mg} / \mathrm{dl})$ * & 282.0 & $(226.1)$ & 227.3 & $(185.1)$ & 231.4 & $(199.7)$ & 1.09 & 0.336 \\
\hline $\mathrm{CRP} *(\mathrm{mg} / \mathrm{L})$ & 2.1 & $(2.3)$ & 1.8 & $(1.6)$ & 1.8 & $(1.8)$ & 0.21 & 0.813 \\
\hline Homocysteine * & 12.3 & $(5.8)$ & 12.2 & $(6.5)$ & 11.1 & $(6.0)$ & 3.48 & 0.031 \\
\hline
\end{tabular}

* Values transformed into logarithm for the statistical test. 
Table 6 - Number and percentage of Japanese-Brazilians according to the values of the ankle-brachial index and demographic, anthropometric, clinical and biochemical variables.

\begin{tabular}{|c|c|c|c|c|c|c|c|c|}
\hline \multirow[t]{2}{*}{ Variável } & & \multicolumn{3}{|c|}{ Ankle-brachial Index } & & & \multirow[b]{2}{*}{ Chi-square } & \multirow[t]{2}{*}{$p$} \\
\hline & & $\begin{array}{r}<0,70 \\
(\%)\end{array}$ & $\begin{array}{c}0,71-0,90 \\
(\%)\end{array}$ & $\begin{array}{l}>0,90 \\
N(\%)\end{array}$ & & $\begin{array}{l}\text { al } \\
\%)\end{array}$ & & \\
\hline \multirow[t]{2}{*}{ Gender } & Female & 2.1 & 20.5 & 77.4 & 565 & $(100)$ & 1.83 & 0.401 \\
\hline & Male & 1.7 & 17.5 & 80.8 & 473 & $(100)$ & & \\
\hline \multirow[t]{2}{*}{ Age } & $<60$ years & 1.0 & 16.8 & 82.2 & 619 & (100) & 13.94 & $<0.001$ \\
\hline & $>60$ years & 3.3 & 22.7 & 74.0 & 419 & $(100)$ & & \\
\hline \multirow[t]{3}{*}{ Smoking 1} & Não & 1.7 & 19.3 & 79.0 & 717 & (100) & 2.92 & 0.572 \\
\hline & Yes (past) & 1.6 & 18.7 & 79.7 & 187 & $(100)$ & & \\
\hline & Yes (current) & 3.9 & 19.2 & 76.9 & 130 & $(100)$ & & \\
\hline \multirow[t]{2}{*}{ Abdominal obesity ${ }^{2}$} & No & 1.2 & 18.9 & 79.9 & 503 & $(100)$ & 2.92 & 0.232 \\
\hline & Yes & 2.6 & 19.4 & 78.0 & 532 & (100) & & \\
\hline \multirow[t]{3}{*}{ Body mass index ${ }^{3}$} & $<23 \mathrm{~kg} / \mathrm{m}^{2}$ & 2.3 & 19.8 & 77.9 & 344 & (100) & 4.66 & 0.324 \\
\hline & 23.0 a $24.9 \mathrm{~kg} / \mathrm{m}^{2}$ & 1.3 & 22.8 & 75.9 & 237 & (100) & & \\
\hline & $>25 \mathrm{~kg} / \mathrm{m}^{2}$ & 2.0 & 16.7 & 81.3 & 456 & (100) & & \\
\hline \multirow[t]{2}{*}{ Hypertension } & No & 0.5 & 17.3 & 82.2 & 567 & (100) & 16.70 & $<0.001$ \\
\hline & Yes & 3.6 & 21.4 & 75.0 & 471 & $(100)$ & & \\
\hline \multirow[t]{4}{*}{ Glucose tolerance } & Normal & - & 13.8 & 86.2 & 58 & (100) & 15.58 & 0.016 \\
\hline & GJA & 0.8 & 18.6 & 80.6 & 377 & (100) & & \\
\hline & TGD & 1.3 & 23.3 & 75.4 & 240 & (100) & & \\
\hline & DM & 3.9 & 18.0 & 78.1 & 362 & (100) & & \\
\hline \multirow[t]{2}{*}{ Hypercholesterolemia } & No & 2.6 & 18.1 & 79.3 & 392 & $(100)$ & 1.66 & 0.437 \\
\hline & Yes & 1.6 & 19.8 & 78.6 & 646 & $(100)$ & & \\
\hline \multirow[t]{2}{*}{ Low HDL } & No & 1.9 & 19.0 & 79.1 & 909 & (100) & 0.23 & 0.891 \\
\hline & Yes & 2.3 & 20.2 & 77.5 & 129 & $(100)$ & & \\
\hline \multirow[t]{2}{*}{ High LDL } & No & 2.2 & 18.7 & 79.1 & 536 & (100) & 0.72 & 0.698 \\
\hline & Yes & 1.6 & 19.7 & 78.7 & 502 & $(100)$ & & \\
\hline \multirow[t]{2}{*}{ Hypertriglyceridemia } & No & 1.1 & 19.6 & 79.3 & 367 & (100) & 2.13 & 0.344 \\
\hline & Yes & 2.4 & 18.9 & 78.7 & 671 & (100) & & \\
\hline \multirow[t]{2}{*}{ CRP } & $<1.1 \mathrm{mg} / \mathrm{L}$ & 2.2 & 17.5 & 80.3 & 509 & (100) & 2.03 & 0.362 \\
\hline & $1.1-9.9 \mathrm{mg} / \mathrm{L}$ & 1.7 & 20.8 & 77.5 & 529 & (100) & & \\
\hline \multirow[t]{2}{*}{ Homocysteine ${ }^{4}$} & $<15 \mathrm{mg} / \mathrm{dL}$ & 2.1 & 17.9 & 80.0 & 700 & (100) & 5.54 & 0.063 \\
\hline & $>15$ mg/dL & 2.5 & 26.9 & 70.6 & 119 & (100) & & \\
\hline
\end{tabular}

${ }^{1}$ Four individuals without information

${ }^{2}$ WHR $>0.80$ for women and $>0.90$ for men

${ }^{3}$ Three individuals excluded without information

${ }^{4}$ One subject without information

${ }^{5}$ Homocysteine available for 819 individuals

A cross-sectional study, "The Tsurugaya Project", similar to ours, also evaluating a population of Japanese origin, noted that patients with higher levels of CRP showed the lower $A B I$ values (OR $2.10[95 \% \mathrm{Cl} 1.133 .88]$ ), independent of other cardiovascular risk factors ${ }^{23}$.

Nevertheless, Wensley et al., in a metaanalysis on levels of CRP and risk of coronary and cerebral disease that included 194,418 individuals, concluded that the causal relationship between atherosclerosis and CRP levels are unlikely. Although there is a linear correlation between levels of CRP and atherosclerotic disease, the relationship weakens sharply after adjusting for other cardiovascular risk factors. According to these authors, CRP may be related to the severity of atherosclerotic disease ${ }^{24}$.

Genetic epidemiology has assisted in obtaining evidence about the involvement of CRP in atherosclerotic disease. The concentration of CRP is a hereditary trait, and there has already been identified the presence of polymorphisms in the CRP gene capable of influencing the circulating level of this protein. These findings open a new research opportunity, since the random allocation of alleles at conception allows a balanced distribution of confounding factors between genotypes. Still, the genotype is not influenced by the presence of disease, the genetic associations then being protected from reverse causality ${ }^{25}$. 
With this objective, Zacho et al. studied the evolution of 51,286 individuals with CRP genotypes responsible for long-term maintenance of high plasma CRP levels and the occurrence of coronary or cerebral disease. They concluded that the polymorphism in the CRP gene was associated with high CRP plasma levels, but not with increased risk of coronary or cerebral ischemia ${ }^{26}$. Other studies evaluating the genetic epidemiology are consistent with the absence of a causal relationship between polymorphisms of the CRP gene with coronary disease ${ }^{26-28}$.

In summary, the published genetic studies ${ }^{24-28}$ were not able to assign a causal role of CRP in atherosclerosis. The development of specific inhibitors for CRP should be of great help to arrive at this answer. Under development lies the 1,6 hexane-diphosphocholine, which has a very short half-life ${ }^{29}$. So far, the actual role of CRP in atherosclerosis is controversial. According to Pepys, CRP is present in atherosclerotic plaques, often collocated with the elements of the complement. The presence at the crime scene, however, is not necessarily evidence of guilt ${ }^{30}$. Our findings suggest that CRP is a marker of severity or intensity of the disease. Since the CRP is released in response to an inflammatory process in the plate, the higher its value, the more intense the local inflammatory reaction. As the intensity of the inflammatory response corresponds to the intensity of atherosclerotic disease, the measurement of CRP may assist in the mapping of patients, identifying those that can evolve with worse prognosis.

\title{
R E S U M O
}

\begin{abstract}
Objetivo: avaliar a relação entre a doença arterial obstrutiva periférica e níveis elevados de proteína C-reativa em população nipobrasileira de alto risco cardiovascular. Métodos: estudo transversal derivado de estudo de base populacional sobre a prevalência de diabetes e doenças associadas em população nipo-brasileira. Mil trezentos e trinta indivíduos com idade >30 foram submetidos a exame clínico e laboratorial, incluindo a dosagem da proteína C-reativa ultrassensível. O diagnóstico da doença arterial obstrutiva periférica foi realizado através do cálculo do índice tornozelo-braço. Foram considerados portadores de doença arterial obstrutiva periférica os pacientes que apresentaram índice tornozelo-braço <0,9. Após aplicação dos critérios de exclusão, 1038 indivíduos completaram o estudo. Resultados: a média de idade da população foi 56,8 anos, $46 \%$ pertencentes ao sexo masculino. A prevalência da doença arterial obstrutiva periférica foi $21 \%$, sem diferença entre os sexos. A análise dos dados não mostrou associação entre doença arterial obstrutiva periférica e proteína C-reativa ultrassensível. Os pacientes com índice tornozelo-braço $<0,70$ apresentaram valores mais elevados de proteína C-reativa ultrassensível e o pior perfil cardiometabólico. Encontramos associação positiva e independente da doença arterial obstrutiva periférica com hipertensão arterial e tabagismo. Conclusão: a associação encontrada entre valores baixos de índice tornozelo-braço e níveis elevados de proteína C-reativa ultrassensível pode sugerir uma relação de gravidade auxiliando mapeamento dos pacientes de maior risco.
\end{abstract}

Descritores: Doença arterial periférica. Proteína C-reativa. Aterosclerose. Homocisteina.

\section{REFERENCES}

1. Brasil. Ministério da Saúde. Saúde 2008: 20 anos de Sistema Único de Saúde (SUS) no Brasil, Brasília/DF, 2009. Disponível em: http:// portal.saude.gov.br/portal/arquivos/pdf/ rat brasil_2008 web 20_11.ppf

2. Fowkers F, Rudan D, Rudan I, Aboyans V, Denenberg JO, McDermott MM, et al. Comparison of global estimates of prevalence and risk factors for peripheral artery disease in 2000 and 2010: a systematic review and analysis. Lancet. 2013;382(9901):1329-40.

3. Ross R. Atherosclerosis - an inflammatory disease. N Engl J Med. 1999;340(2):115-26.

4. Szmitko PE, Wang CH, Weisel RD, de Almeida JR, Anderson TJ, Verna S. New markers of inflammation and endothelial cell activation: Part I. Circulation. 2003;108(16):1917-23.

5. Danesh J, Wheeler JG, Hirschfield GM, Eda S, Eiriksdottir G, Rumley $A$, et al. C-reactive protein and other circulating markers of inflammation in the prediction of coronary heart disease. $\mathrm{N}$ Engl J Med. 2004;350(140:1387-97

6. Momiyama Y, Kawaguchi A, Kajiwara I, Ohmori R, Okada K, Saito I, et al. Prognostic value of plasma high-sensitivity $C$-reactive protein levels in Japanese patients with stable coronary artery disease: the Japan NCVC-Collaborative Inflammation Cohort (JNIC) Study. Atherosclerosis. 2009;207(1):272-6
7. Hingorani AD, Shah T, Casas JP, Humphries SE, Talmud PJ. Creactive protein and coronary heart disease: predictive test or therapeutic target? Clin Chem. 2009;55(2):339-55.

8. Ridker PM, Cushman M, Stampfer MJ, Tracy RP, Hennekens $\mathrm{CH}$. Plasma concentration of $\mathrm{C}$-reactive protein and risk of developing peripheral vascular disease. Circulation. 1998:97(5):425-8.

9. Fujimoto WY, Leonetti DL, Kinyoun JL, Newell-Morris L, Shuman WP, Stolov WC, et al. Prevalence of diabetes mellitus and impaired glucose tolerance among second-generation Japanese-American men. Diabetes. 1987;36(6):721-9.

10. Lerario DDG, Gimeno SG, Franco LJ, lunes M, Ferreira SRG. Excesso de peso e gordura abdominal para a síndrome metabólica em nipo-brasileiros. Rev Saúde Pública. 2002;36(1):4-11.

11. Gimeno SG, Ferreira SR, Cardoso MA, Franco LJ, lunes M. Weight gain in adulthood and risk of developing glucose tolerance disturbance: a study of a Japanese-Brazilian population. JapaneseBrazilian Study Group. J Epidemiol. 2002;10(2):103-10.

12. Examination Committee of Criteria for 'Obesity Disease' in Japan; Japan Society for the Study of Obesity. New criteria for 'obesity disease' in Japan. Circ J. 2002;66(11):987-92.

13. WHO Expert Consultation. Appropriate body-mass index for Asian populations and its implications for policy and intervention strategies. Lancet. 2004;363(9403):157-63.

14. Chobanian AV, Bakris GL, Black HR, Cushman WC, Green LA, Izzo $J \mathrm{~L} J$ r, et al. The Seventh Report of the Joint National Committee 
on Prevention, Detection, Evaluation, and Treatment of High Blood Pressure: the JNC 7 report. JAMA. 2003;289(19):2560-72.

15. Grundy SM, Cleeman JI, Merz CN, Brewer HB Jr, Clark LT, Hunninghake DB, et al. Implications of recent clinical trials for the National Cholesterol Education Program Adult Treatment Panel III guidelines. Circulation. 2004;110(2):227-39. Erratum in: Circulation. 2004;110(6):763.

16. American Diabetes Association. Standards of medical care in diabetes-2011. Diabetes Care. 2011;34 Suppl 1:S11-61.

17. Garofolo L, Barros N Jr, Miranda F Jr, D'Almeida V, Cardien LC, Ferreira SR. Association of increased levels of homocysteine and peripheral arterial disease In Japanese-Brazilian population. Eur J Vasc Endovasc Surg. 2007;34(1):23-8

18. Norgren L, Hiatt WR, Dormandy JA, Nehler MR, Harris KA, Fowkes FG; TASC II Working Group. Inter-Society Consensus for the Management of Peripheral Arterial Disease (TASC II). J Vasc Surg. 2007;45 Suppl S:S5-67.

19. McDermott MM, Green D, Greenland P, Liu K, Criqui MH, Chan C, et al. Relation of levels of hemostatic factors and inflammatory markers to the ankle brachial index. Am J Cardiol. 2003:92(2):194-9.

20. Belch J, MacCuish A, Campbell I, Cobbe S, Taylor R, Prescott R, et al. The prevention of progression of arterial disease and diabetes (POPADAD) trial: factorial randomised placebo controlled trial of aspirin and antioxidants in patients with diabetes and asymptomatic peripheral arterial disease. BMJ. 2008;337:a1840.

21. Schunkert $H$, Samani NJ. Elevated C-reactive protein in atherosclerosis—chicken or egg? N Eng J Med. 2008;359(18):1953-5.

22. Miller $M$, Zhan $M$, Havas S. High attributable risk of elevated Creactive protein level to conventional coronary heart disease risk factors: the Third National Health and Nutrition Examination Survey. Arch Intern Med. 2005;165(18):2063-8.

23. Hozawa A, Ohmori K, Kuriyama S, Shimazu T, Niu K, Watando A, et al. C-reactive protein and peripheral arterial disease among Japanese elderly: the Tsurugaya Project. Hypertens Res. 2004;27(12):955-61.
24. C Reactive Protein Coronary Heart Disease Genetics Collaboration (CCGC), Wensley F, Gao P, Burgess S, Kaptoge S, Di Angelantonio $E$, et al. Association between $C$ reactive protein and coronary heart disease: mendelian randomization analysis based in individual participant data. BMJ. 2011;342:d548.

25. Brull DJ, Serrano N, Zito F, Jones L, Montgomery HE, Rumley A, et al. Human CRP gene polymorphism influences CRP levels: implications for the prediction and pathogenesis of coronary heart disease. Atheroscler Thromb Vasc Biol. 2003:23(11):2063-9. Erratum in: Atheroscler Thromb Vasc Biol. 2004;24(7):1328.

26. Zacho J, Tybjaerg-Hansen A, Jensen JS, Grande P, Sillesen $H$, Nordestgaard BG. Genetically elevated C-reactive protein and ischemic vascular disease. N Eng J Med. 2008;359(18):1897-908.

27. Elliot P, Chambers JC, Zhang W, Clarke R, Hopewell JC, Peden JF, et al. Genetic Loci associated with $C$-reactive protein levels and risk of coronary heart disease. JAMA. 2009;302(1):37-48.

28. Casas JP, Shah T, Cooper J, Hawe E, McMahon AD, Gaffney D, et al. Insight into the nature of the CRP-coronary event association using Mendelian randomization. Inter J Epidemiol. 2006;35(4):92231.

29. Pepys MB, Hirschfield GM, Tennent GA, Gallimore JR, Kahan MC, Bellotti $\mathrm{V}$, et al. Targeting C-reactive protein for the treatment of cardiovascular disease. Nature. 2006;440(7088):1217-21.

30. Pepys MB. CRP or not CRP? That is the question. Arterioscle Thromb Vasc Biol. 2005;25(6):1091-4.

Received on $17 / 03 / 2013$

Accepted for publication 10/05/2013

Conflict of interest: none.

Source of funding: none.

Address for correspondence:

Luciana Garofolo

E-mail: Igarofolo@ig.com.br 